Cronfa - Swansea University Open Access Repository

This is an author produced version of a paper published in :

Archives of Agronomy and Soil Science

Cronfa URL for this paper:

http://cronfa.swan.ac.uk/Record/cronfa32452

\title{
Paper:
}

Atanassova, I., Hristov, B., Shishkov, T. \& Doerr, S. (2017). Lipid biomarkers and their environmental significance in mine soils from Eastern Europe. Archives of Agronomy and Soil Science, 1-14.

http://dx.doi.org/10.1080/03650340.2017.1304639

This article is brought to you by Swansea University. Any person downloading material is agreeing to abide by the terms of the repository licence. Authors are personally responsible for adhering to publisher restrictions or conditions. When uploading content they are required to comply with their publisher agreement and the SHERPA RoMEO database to judge whether or not it is copyright safe to add this version of the paper to this repository. http://www.swansea.ac.uk/iss/researchsupport/cronfa-support/ 


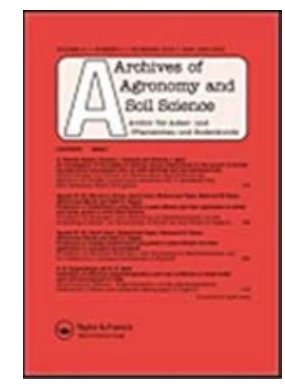

\section{Lipid biomarkers and their environmental significance in mine soils from Eastern Europe}

\begin{tabular}{|r|l|}
\hline Journal: & Archives of Agronomy and Soil Science \\
\hline Manuscript ID & GAGS-2016-0799.R2 \\
\hline Manuscript Type: & Original Article \\
\hline Keywords: & soil, mining, soil quality, water \\
\hline \multicolumn{2}{l}{} \\
\hline
\end{tabular}

SCHOLARONE ${ }^{\mathrm{m}}$

Manuscripts 

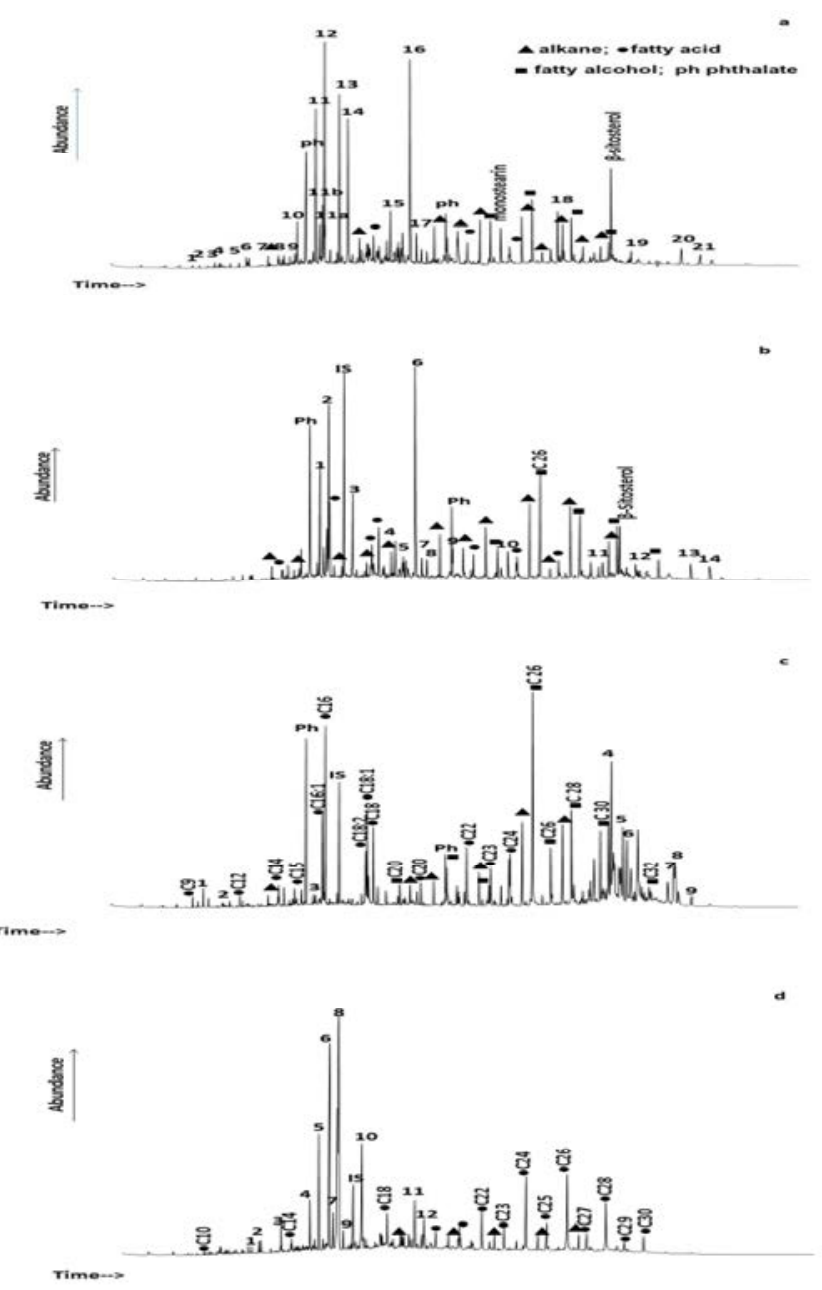

$215 \times 279 \mathrm{~mm}(200 \times 200 \mathrm{DPI})$ 
Figure 2
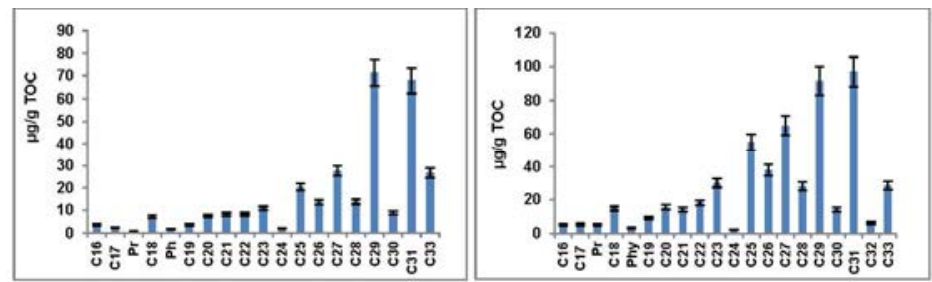

(a)

(b)
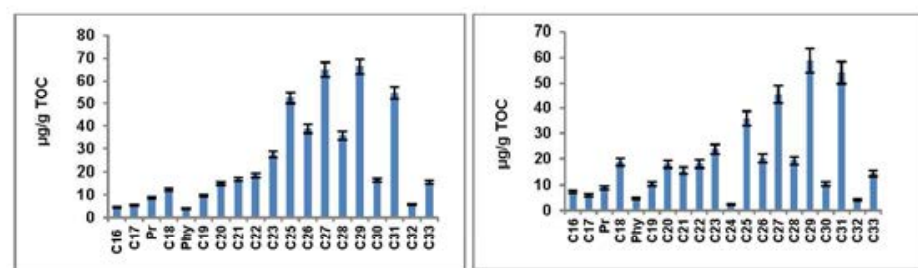

(c)

(d)

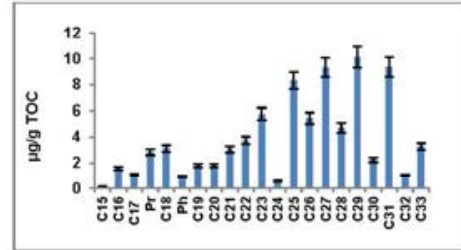

(e)
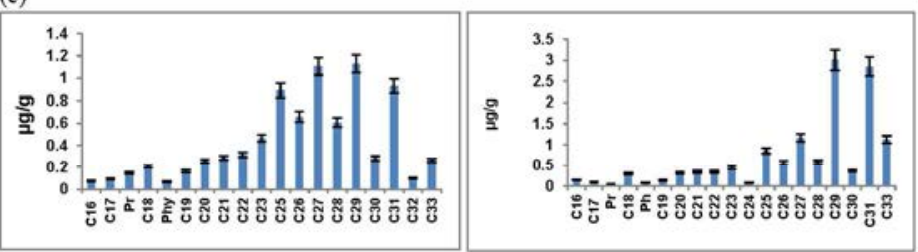

(f)

(g)

$215 \times 279 \mathrm{~mm}(200 \times 200 \mathrm{DPI})$

URL: http://mc.manuscriptcentral.com/GAGS E-mail: galina.machulla@landw.uni-halle.de 
Figure 3
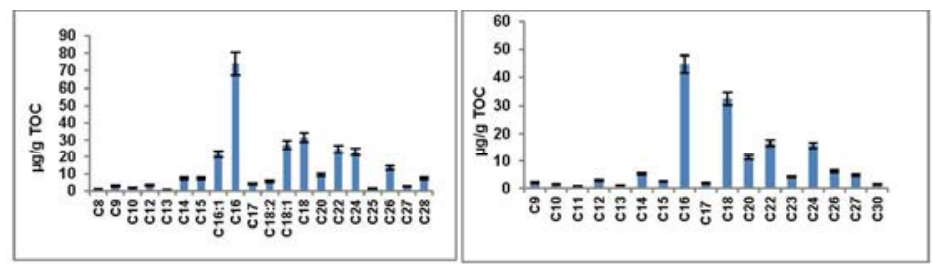

(a)

(b)
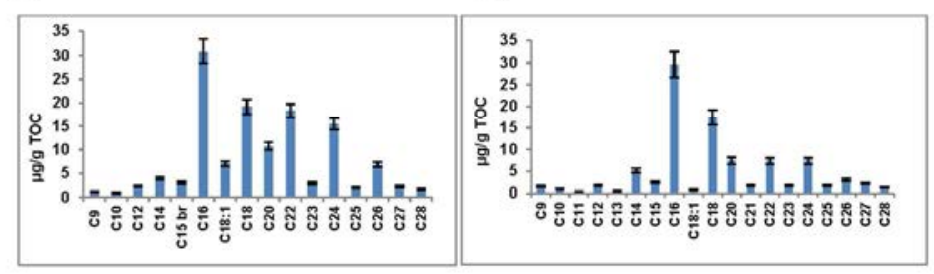

(c)

(d)

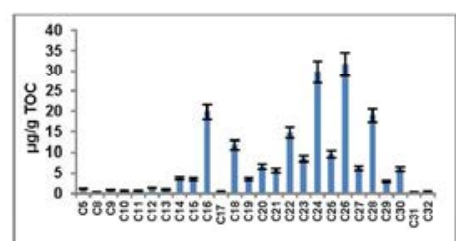

(e)

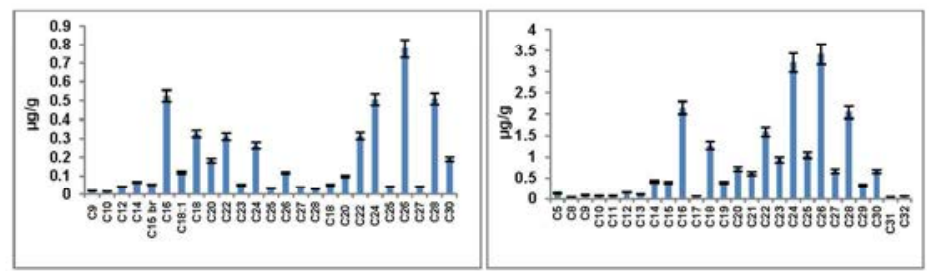

(f)

(g)

$215 \times 279 m m(200 \times 200$ DPI $)$

URL: http://mc.manuscriptcentral.com/GAGS E-mail: galina.machulla@landw.uni-halle.de 
Figure 4
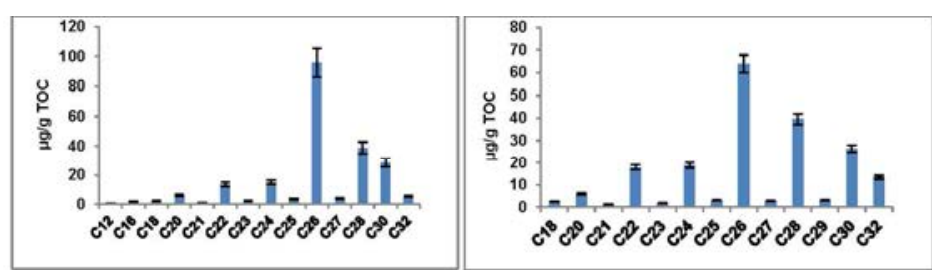

(a)

(b)

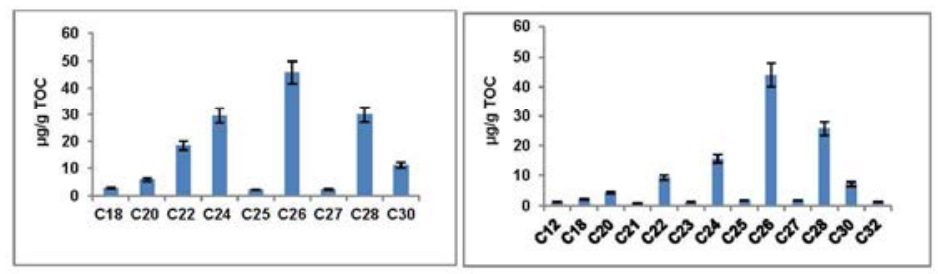

(c)

(d)

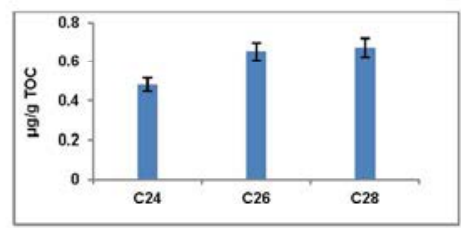

(e)
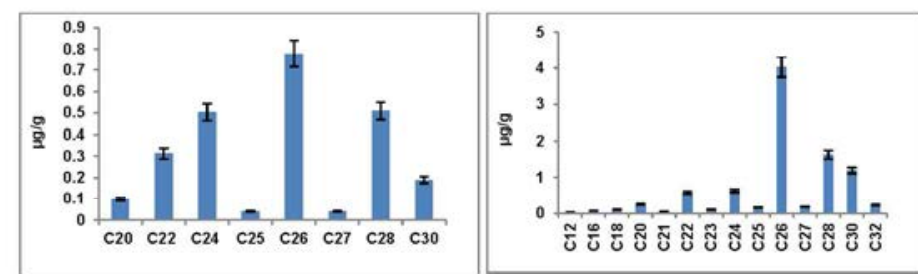

(f)

(g)

$215 \times 279 m m(200 \times 200$ DPI $)$

URL: http://mc.manuscriptcentral.com/GAGS E-mail: galina.machulla@landw.uni-halle.de 
Table 1. Chemical and physical properties of the experimental soils.

\begin{tabular}{|c|c|c|c|c|c|c|}
\hline $\begin{array}{l}\text { Soil type }^{a} \\
\text { Depth } \\
(\mathrm{cm})\end{array}$ & GPS & $\begin{array}{c}\mathrm{pH} \\
\mathrm{H}_{2} \mathrm{O}\end{array}$ & $\begin{array}{l}\mathrm{EC} \\
\mathrm{mS} \\
\mathrm{cm}^{-1}\end{array}$ & $\begin{array}{c}\text { CEC } \\
\mathrm{cmol} \mathrm{kg}^{-1}\end{array}$ & $\begin{array}{l}\mathrm{OC} \\
\%\end{array}$ & $\begin{array}{c}\mathrm{WDPT}^{\mathrm{b}} \\
\text { (s) }\end{array}$ \\
\hline $\begin{array}{l}\text { Bathycalcic Vertisol } \\
0-5\end{array}$ & $\begin{array}{l}\text { N42.61068 } \\
\text { E23.00614 }\end{array}$ & 7.2 & $\begin{array}{c}0.05 \\
\pm 0.01\end{array}$ & $\begin{array}{l}58.9 \\
\pm 1.5\end{array}$ & $\begin{array}{c}4.2 \\
\pm 0.3\end{array}$ & 1740 \\
\hline $\begin{array}{l}\text { Spolic Technosol } \\
\text { (Reclaimed mine soil } \\
\text { under grass RMS-G) } \\
0-5\end{array}$ & $\begin{array}{l}\text { N42.62037 } \\
\text { E23.03409 }\end{array}$ & 7.7 & $\begin{array}{c}0.29 \\
\pm 0.05\end{array}$ & $\begin{array}{l}34.1 \\
\pm 0.5\end{array}$ & $\begin{array}{c}1.6 \\
\pm 0.2\end{array}$ & $<5$ \\
\hline $\begin{array}{l}\text { Spolic Technosol } \\
\text { (Reclaimed coal spoil } \\
\text { under pine RMS-PI) } \\
0-5\end{array}$ & $\begin{array}{l}\text { N42.62037 } \\
\text { E23.03409 }\end{array}$ & 8.1 & $\begin{array}{c}0.04 \\
\pm 0.01\end{array}$ & $\begin{array}{l}42.0 \\
\pm 0.8\end{array}$ & $\begin{array}{c}1.7 \pm \\
0.2\end{array}$ & $<5$ \\
\hline $\begin{array}{l}\text { Spolic Technosol } \\
\text { (RMS-PII) } \\
10-15\end{array}$ & & 8.0 & $\begin{array}{c}0.04 \\
\pm 0.01\end{array}$ & $\begin{array}{l}35.3 \\
\pm 1.2\end{array}$ & $\begin{array}{r}1.5 \\
\pm 0.3\end{array}$ & $<5$ \\
\hline $\begin{array}{l}\text { Unreclaimed } \\
\text { coal spoil (UCS) } \\
0-5\end{array}$ & $\begin{array}{l}\text { N42.62037 } \\
\text { E23.02932 }\end{array}$ & 3.3 & $\begin{array}{c}0.48 \\
\pm 0.05\end{array}$ & $\begin{array}{l}59.4 \\
\pm 0.6\end{array}$ & $\begin{array}{l}10.8 \\
\pm 0.8\end{array}$ & 8220 \\
\hline
\end{tabular}

\footnotetext{
${ }^{a}$ Hristov et al. 2015; IUSS Working Group WRB. 2015

${ }^{\mathrm{b}}$ Median of three WDPT measurements
} 


\section{Archives of Agronomy and Soil Science}

Table 2. Compounds ratios.

\begin{tabular}{|c|c|c|c|c|c|c|c|c|}
\hline Site & $\begin{array}{l}\text { Depth } \\
(\mathrm{cm})\end{array}$ & $\begin{array}{l}\text { CPI } \\
\text { Alk whole }\end{array}$ & $\begin{array}{l}\text { CPI } \\
\text { Alk short }\end{array}$ & $\begin{array}{l}\text { CPI } \\
\text { Alk long }\end{array}$ & $\begin{array}{l}\text { CPI } \\
\text { long/shor } \\
t\end{array}$ & $\mathrm{Pr} / \mathrm{Ph}$ & $\mathrm{Pr} / \mathrm{C}_{17}$ & $\mathrm{Ph} / \mathrm{C}_{18}$ \\
\hline Vertisol & $0-5$ & 3.74 & 0.88 & 5.97 & 6.78 & 0.53 & 0.42 & 0.27 \\
\hline Reclaimed mine soil & & & & & & & & \\
\hline under grass (RMS-G) & $0-5$ & 2.79 & 1.06 & 3.90 & 3.69 & 1.48 & 0.94 & 0.23 \\
\hline Reclaimed mine soil & & & & & & & & \\
\hline under pine (RMS-PI) & $0-5$ & 2.34 & 1.18 & 2.62 & 2.23 & 2.22 & 1.63 & 0.32 \\
\hline (RMS-PII) & $10-15$ & 2.23 & 0.86 & 3.85 & 4.47 & 1.93 & 1.49 & 0.25 \\
\hline $\begin{array}{l}\text { Unreclaimed } \\
\text { coal spoil (UCS) }\end{array}$ & $0-5$ & 2.16 & 1.10 & 3.01 & 2.7 & 3.06 & 2.63 & 0.30 \\
\hline
\end{tabular}

\footnotetext{
* NA not analysed due to lack of odd numbered homologues
} 


\title{
Lipid biomarkers and their environmental significance in mine soils from Eastern Europe
}

\author{
Atanassova, Irena ${ }^{\mathrm{a}}$, Hristov, Biser ${ }^{\mathrm{a}}$, Shishkov, Toma ${ }^{\mathrm{a}}$, Doerr, Stefan ${ }^{\mathrm{b}}$ \\ ${ }^{\mathrm{a}}$ N. Poushkarov Institute of Soil Science, Agrotechnologies and Plant Protection Sofia, \\ Bulgaria; ${ }^{b}$ College of Science, Department of Geography, Swansea University, \\ Swansea, UK
}

Corresponding author. Email: i.d.atanassova@abv.bg

\begin{abstract}
The present study describes signature lipid biomarkers in reclaimed mine soils, an unreclaimed spoil and a natural soil (Vertisol) for a major coal mine basin in Eastern Europe. Alkanes, fatty acids and fatty alcohols, as well as coal biomarkers were abundant in the mine soils and the unreclaimed spoil. The alkanes distribution in the reclaimed mine soils was bimodal with maxima at $\mathrm{C}_{18}$ and $\mathrm{C}_{29} \backslash \mathrm{C}_{31}$ and points at two origins for the alkanes, terrigenous plants, including soil borne and from the coal source. Fatty acid carbon preference indices $\left(\mathrm{CPI}_{\text {even/odd }}=10.4\right.$ and 8.1 for the mine soils under pine and grass vegetation) reflect the increasing role of terrestrial vegetation in the formation of organic matter. The higher concentrations of the long chain alkanes, fatty acids and alcohols are speculated as the reason for the severe and extreme water repellency observed with the Vertisol and the unreclaimed spoil. The presence of terrigenous steroid and triterpenoid markers in the reclaimed mine soils is an indication of the ongoing soil formation processes. The analysis of lipid extracts allowed for the assessment of sensitive molecular indicators of biogenic terrigenous and coal origin and the degree of soil recovery following $>20$ years of spoils reclamation.
\end{abstract}

Keywords: lipid biomarkers, mine soils, coal, sources, water repellency

\section{Introduction}

URL: http://mc.manuscriptcentral.com/GAGS E-mail: galina.machulla@landw.uni-halle.de 
The restoration of disturbed mine soils is a common practice in many countries following mining activities for ecological, social and economic reasons (Macdonald et al. 2015). These reclaimed soils are subject to increasing scientific interest given that relatively little is currently known about their soil forming properties. An important aspect of the rehabilitation process is the amelioration of mine waste material to sustain soil productivity. A common practice frequently applied is the application of a soil cover layer, which assists in the prevention of further oxidation of low-base-content overburden consisting of a mix of sandstone, pyrites, and waste coal and facilitates the subsequent revegetation of the site (Barnhisel \& Hower 1997). Forestation has a beneficial effect on initial soil-forming processes in surface coal mine spoils (Haigh \& Gentcheva-Kostadinova 2007; Krümmelbein et al. 2012). Spatial variability and substantial heterogeneity of total nitrogen and soil organic carbon (SOC) was estimated in mine soils using geostatistical analysis (Wang et al. 2015). In addition, lignitic mine soils exhibit spatial small-scale variability of water repellency due to partial mixing of different overburden sediments, which corresponded with the spatial distribution of lignite, minerals, and lignite-coated sand particles and influenced water and solute movement in reclaimed soils (Gerke et al. 2001). Reclaimed coal mine areas are often characterized by highly eroded slopes due to water repellency (Krummelbein et al. 2012). Organic geochemical marker analysis of lignites has revealed the presence of various compound classes such as alkanes, branched, saturated and unsaturated fatty acids, aliphatic and steroid alcohols, ketones, aldehydes and terpenoids (Stefanova et al. 2016). Biomarker patterns of Pernik coal basin indicate dominance of conifer vegetation in the coal-forming mire (Stefanova et al. 2013). Chaudhuri et al. (2015) have observed that SOC molecular characteristics play a key role in overall SOC dynamics and significant relationships exist between the spectroscopic indices and different soil quality parameters in mine soils. 
Although, profiles of phospholipid fatty acids (PLFAs) responding to different carbon substrates and yielding significant data of soil communities upon soil rehabilitation have been assessed (Claassens et al. 2006) and general soil characteristics improved upon spoil reclamation (Zhao et al. 2013) to our knowledge there are no data on geochemical proxies in reclaimed coal spoils-turned soils and their environmental implication. The major aims of the present study are: (i) to analyse organic geochemical markers of biogenic terrigenous and coal origin in reclaimed coal mine soils, unreclaimed coal spoil and a natural soil from the Pernik brown coal basin, and (ii) assess their origin and respectively the recovery of ecosystem structure following $>20$ year period of reclamation at the mine spoils.

\section{Materials and methods}

\section{Study sites and soil properties}

In the Pernik coal mine basin the major geologic materials of the stratigraphic profile are marls mixed with quartz and feldspars and secondary minerals montmorillonite, illite, kaolinite and carbonates (6.9-24\%) also present (Gushevilov \& Paskaleva 1977). The black coal shales, i.e. clay layers intermixed with coal, as well as cinder, a product of burning black coal shales are characterized by the presence of sulfur-containing minerals, such as pyrite. The study was done in the vicinity of Bela Voda mine and Alexander Milenov mine, the town of Pernik, Bulgaria and concerns $>20$ years biologically reclaimed coal spoils under pine and grass species, a non-vegetated unreclaimed coal spoil, representing a road embankment, formed from medium quality brown coals, and a natural soil (Bathycalcic Vertisol, IUSS Working Group WRB 2015). Two depths of the reclaimed mine soil under pine (RMS PI and RMS PII) were analysed (Table 1), because physical parameters, viz. water retention, aggregate composition and aggregate stability differed for this site (preliminary unpublished data). Soils were sampled in four replicates at five randomly selected spots up to $30 \mathrm{~m}$ away from each other. At the reclaimed mine soil under pine (RMS-PI) and grass (RMS-G) URL: http://mc.manuscriptcentral.com/GAGS E-mail: galina.machulla@landw.uni-halle.de 
and for the natural Vertisol the litter and grass layers were removed and the upper $5 \mathrm{~cm}$ of the mineral soil were sampled by a hand auger $(7.6 \mathrm{~cm}$ in diameter). Samples were air-dried and passed through a 2-mm sieve before further analysis. The coning and quartering method was used to reduce the samples variability. Locations, sites characteristics and soil classification are presented in Table 1. Organic carbon (OC) in the studied spoils and the soil was determined with the modified Tyurin's method (oxidation with $\mathrm{K}_{2} \mathrm{Cr}_{2} \mathrm{O}_{7} / \mathrm{H}_{2} \mathrm{SO}_{4}$, Kononova 1966), cation exchange capacity was determined as sum of titratable acidity ( $\mathrm{pH} 8.2$ ) and extractable $\mathrm{Ca}$, by saturation with $\mathrm{K}$ malate ( $\mathrm{pH}$ 8.2) (Ganev \& Arsova 1980). Total porosity (P) was calculated using the measured bulk density $\left(\rho_{\mathrm{b}}\right)$ on undisturbed soil cores $\left(100 \mathrm{~cm}^{3}\right)$ and particle density determined in water (ISO 11508:1998). Sample water-repellency was measured by the water drop penetration time (WDPT) method (Doerr et al. 2002). Three droplets of distilled water $(\sim 80 \mu \mathrm{l})$ were placed on the soil surface and the time recorded for droplet penetration.

\section{Lipids analysis}

The extractions were performed by sonication of the soils (5 $\mathrm{g}$ in duplicate) in $20 \mathrm{ml}$ of acetone: hexane (1:1 vs/v) using a Julabo USR 3, $35 \mathrm{kHz}, 200 \mathrm{~W}$, Julabo Labortechnik GMBH for $3 \mathrm{~min}$. The extraction was repeated twice with fresh solvent. The combined solvent extracts were dried with $\mathrm{Na}_{2} \mathrm{SO}_{4}$, vacuum-evaporated (Labconco CentriVap concentrator at $\left.50^{\circ} \mathrm{C}\right)$ and solvent exchanged into dichlorometane:iso-propanol (2:1). Then $100 \mu \mathrm{l}$ of $0.2 \mu \mathrm{g} / \mu \mathrm{l}$ 2-nonadecanone was added, vacuum dried then derivatized with $50 \mu \mathrm{l}$ of BSTFA $+1 \%$ TMCS (heating for 1 hour at $70^{\circ} \mathrm{C}$ ) and excess of BSTFA gently evaporated (Atanassova \& Mills 2016, modified). After completion of derivatization, the derivatives were cooled and gently dried. Then four replication vials per soil sample were reconstituted to $300 \mu \mathrm{l}$ with DCM, and analysed by GC/MS.

\section{Gas chromatography-mass spectrometry (GC/MS)}


The gas chromatograph (Agilent 7890A) and equipped with a 5975 C mass-selective detector (splitless injection mode) was used for analysis of the extracts. Separation was carried out on HP-5ms capillary columns $(30 \mathrm{~m} \times 0.25 \mathrm{~mm}$ I.D., film thickness, $0.25 \mu \mathrm{m})$ and He was used as a carrier gas. The GC programme was: initial $\mathrm{T} 60^{\circ} \mathrm{C}$, hold $1 \mathrm{~min}$, linear ramp $10^{\circ} \mathrm{C} / \mathrm{min}$ to $180^{\circ} \mathrm{C}$ and then ramped at $4 \%$ min to $300^{\circ} \mathrm{C}$, and held for 15 $\min$. The MS detection was full scan, mass to charge ratio $(\mathrm{m} / \mathrm{z}) 50-1000$, cycle time $2.28 \mathrm{scans} / \mathrm{s}$ and EI ionization $70 \mathrm{eV}$. Identification was based on comparing the mass spectra of the chromatographic peaks to those reported in the NIST-MS library, comparisons with authentic standards, published data, GC retention times and interpretation of mass fragmentation patterns.

\section{Quantification}

For quantitative analysis, the GC-MS was calibrated with pure reference compounds i.e. n-alkanes, acids and alcohols. The fragment ions used for quantification were: $\mathrm{m} / \mathrm{z}$ 57 for the n-alkanes, m/z 75 for the n-alcohols, and m/z 117 for the $n$-fatty acids. The peak areas for each component were compared to the peak area of the fragment ion $(\mathrm{m} / \mathrm{z}$ 58) of the 2-nonadecanone standard by assuming the same response factor for analytes as for the internal standard. Differences between compounds contents in the samples were assessed by Tukey's test at $\mathrm{p}=0.05$ (SPSS 22).

\section{Compound ratios}

Compound ratios (Carbon Preference Indices CPI) are valuable tools in providing information on various sources of soil organic matter. The following ratios were calculated: $\mathrm{CPI}_{1}=\Sigma\left(\mathrm{C}_{13}-\mathrm{C}_{35}\right) / \Sigma\left(\mathrm{C}_{12}-\mathrm{C}_{34}\right)$ for the whole range of detected alkanes, for the short chain $n$-alkanes: $\mathrm{CPI}_{2}=\Sigma\left(\mathrm{C}_{13}-\mathrm{C}_{25}\right) / \Sigma\left(\mathrm{C}_{12}-\mathrm{C}_{24}\right)$ and long chain $n$-alkanes: $\mathrm{CPI}_{3}=$ $\Sigma\left(\mathrm{C}_{25}-\mathrm{C}_{35}\right) / \Sigma\left(\mathrm{C}_{24}-\mathrm{C}_{34}\right)$ (Lichtfouse and Eglinton 1995). The CPI for fatty acids (fatty alcohols) $=$ Eeven $/$ Sodd homologues (Matsumoto et al. 2007) and the ratio of short to long fatty acids $\left(\mathrm{FA}_{\text {short }} / \mathrm{FA}_{\text {long }}\right)=\Sigma \mathrm{C}_{9^{-20}} / \Sigma \mathrm{C}_{21-34}$ were calculated. 


\section{General soil properties}

Determination of organic carbon concentration in the mine soils is complicated because of a mixture of fossil carbon and recently deposited carbon from the organic material (Ussiri \& Lal 2005), but it is possible to differentiate between sources of soil organic matter (SOM), based on the molecular signature of the "free lipid" fraction. The reclaimed soils possess slightly alkaline soil reaction, while the eroded unreclaimed spoil was very acid similarly to former observations of reclaimed soils from the area of the Pernik mines (Haigh \& Gentcheva-Kostadinova 2002). The CECs of the Vertisol and the eroded unreclaimed spoil and organic carbon contents were the highest and corresponded with the content of smectite in Vertisols (Gushevilov \& Paskaleva 1977) while the bulk density was the lowest. These parameters corresponded with the higher water repellency determined for these samples as reflected by the WDPTs (Table 1). The variations between the soil physical parameters such as soil bulk density, porosity and soil aggregation in the coal spoils are suggested to be caused by variations in organic carbon contents. It's well known that organic matter acts as a bonding agent in the formation of soil aggregates by affecting aggregation, increasing porosity and decreasing bulk density, as observed for the spoils and the natural soil (Table 1). The higher values for the electrical conductivity (EC) of the mine soil under grass (RMS-G) and unreclaimed coal spoil (UCS) are most probably due to the salinity in the coal mine environments originating from geogenic salt accumulations (Park et al. 2013) and weathering of spoils upon surface exposure. We speculate that the lower levels of EC observed in RMS-PI are caused by local leaching of salts by water in these better drained (pine plantation) soils.

\section{Total ion current chromatograms (TIC) of total lipid extracts (TLE)}

The TIC chromatograms of the mine soils under pine (RMS-PI, Figure 1a) are dominated by dehydroabietic acid (8.8\%); phyllocladane (8.7\%); 4,4'URL: http://mc.manuscriptcentral.com/GAGS E-mail: galina.machulla@landw.uni-halle.de 
diacetyldiphenylmethane $\quad(5.9 \%) ; \quad 18$-norabietane $\quad(5.7 \%) ; \quad \beta$-sitosterol $\quad(3.8 \%)$; cyclohexene, 4-pentyl-1-(4-propylcyclohexyl)- (2.3\%); pimaric acid (2.2\%); 4isopropyl-7,11-dimethyl-3,7,11 cyclotetradecatrienone (1.4\%); abietic acid (1.3\%); stigmast-4-en-3-one (0.7\%) and triterpenoids 30-norlupan-28-oic acid, 3-hydroxy-21methoxy-20-oxo-, methyl ester, $(3 \beta)$ - (1\%) and C(14a)-Homo-27-norgammacer-13-en21-one, 3-methoxy-, $(3 \alpha)(0.7 \%)$. All these compounds account for $42.5 \%$ of TIC. The rest of the compounds signature in the mine soils under pine is represented by homologous series of alkanes, fatty acids and fatty alcohols. Sesquiterpenoids represented only a minor fraction $(\sim 1 \%)$ of TIC chromatogram. The TLE of the mine soil under grass (RMS-G, Figure $1 \mathrm{~b}$ ) is dominated by similar compounds as shown by the high dominance of a signal from coal, i.e. dehydroabietic acid (7.6\%); phyllocladane (5.2\%); 18-norabietane (3.4\%); 4,4'-diacetyldiphenylmethane (2.7\%); 4-isopropyl-7,11dimethyl-3,7,11 cyclohexene, 4-pentyl-1-(4-propylcyclohexyl)- $\quad(1.9 \%)$; cyclotetradecatrienone $(1.14 \%)$ and biomarkers pimaric acid $(1.3 \%)$, isopimaric acid $(0.6 \%)$, methyldehydroabietate $(0.7 \%)$; abietic acid $(0.7 \%)$ originating from coniferous vegetation and vascular plant biomarkers such as $\beta$-sitosterol. The analysis of TIC of the unreclaimed coal spoil (Figure 1d) shows the predominance of five major compounds similarly to the TIC of the mine soils but present at higher abundance. The most abundant compounds (in order of elution) were: 18-norabietane (12.4\%); 4-isopropyl7,11-dimethyl-3,7,11 cyclotetradecatrienone (1.6\%); cyclohexene, 4-pentyl-1-(4propylcyclohexyl)- (7.3\%); phyllocladane (14.6\%); azelaic acid $(0,73 \%)$; 7-isopropyl1,1,4a-trimethyl-1,2,3,4,4a,9,10,10a-octahydrophenanthrene (dehydroabietane $0.5 \%$ ). This diterpene hydrocarbon is a marker of the oleoresin of the pine (Vlad et al., 1971). Other dominant compounds were 4,4'-diacetyldiphenylmethane $\quad(4.6 \%)$; methylpimaran-18-oate $(2.4 \%)$ and dehydroabietic acid (1\%). These enumerated compounds account for as much as $45 \%$ of the TIC of TLEs. The rest of the compounds are represented by homologous series of alkanes and fatty acids (chain length $>\mathrm{C}_{20}$ ). URL: http://mc.manuscriptcentral.com/GAGS E-mail: galina.machulla@landw.uni-halle.de 
The terrigenous plant biomarkers such as $\beta$-sitosterol and stigmasterol, as well as the ubiquitous palmitic acid $\left(\mathrm{C}_{16}\right)$ are missing in this spoil. For the natural Vertisol (Figure 1c) the compound signature was dominated mainly by homologous series of alkanes, fatty acids and alcohols ( $\sim 80 \%$ TIC) with substantial input of $\beta$-sitosterol $(2.8 \%)$ and triterpenoids: 4,4-dimethyl-3-hydroxy]cholesta-8,24-diene (2.6\%); lup-20(29)-en-3-ol, acetate, (3ß)- (2.3\%); lanosta-8,24-dien-3-ol, acetate, $(3 \beta)$ - (1.9\%); lupeol (1.7\%); 30norlupan-28-oic acid, 3-hydroxy-21-methoxy-20-oxo-, methyl ester, (3ß)- (1.7\%). All these compounds account for $13 \%$ of TIC. The detection of animal sterols such as cholesterol and cholesterol derivatives, viz. 4-methyl-3-[(hydroxy]cholest-5-ene (M+ 472 ) is directly related to micro- and meso-fauna biomass. (Figures 1a, b, c, d near here)

\section{Alkanes}

The $n$-alkanes extend from $\mathrm{C}_{16}$ to $\mathrm{C}_{33}$ (Figure 2) and exhibit bimodal distribution maximizing at $\mathrm{C}_{18}$ and $\mathrm{C}_{29}\left(\mathrm{C}_{31}\right)$. The origin of these substances is evidenced by calculation of the carbon preference index (CPI) widely used in organic geochemistry to measure odd/even carbon preference (Tissot \& Welte 1984). Alkanes can be classified in two groups according to their sources. The first group comprises short-chain $n$ alkanes extending from $\mathrm{C}_{15}$ to $\mathrm{C}_{20}$ derived from coal sources. The absence of odd/even predominance is typical of organic matter subjected to high temperature and pressure stress through geological times as in coal (Tissot \& Welte 1984). Long-chain $n$-alkanes extending from $\mathrm{C}_{24}$ to $\mathrm{C}_{33}$ show a strong odd carbon-number predominance with $\mathrm{CPI}$ values ranging from 2.2 to 6.0 (Table 2). A strong odd/even predominance is typical of $n$-alkanes found in plant cuticular waxes (Bryselbout et al. 1998) and in lowcontaminated soils (Lichtfouse et al. 1997). These distributions point at two origins for the alkanes, terrigenous plants, including soil borne and from the coal source, because of the lack of prevalence of short chain odd-numbered alkanes typical of microbial 
sources (Table 2). In our study, data range from $\mathrm{CPI}=2.16$ (unreclaimed coal spoil) to $\mathrm{CPI}=2.79$ (reclaimed soil under grass) and $\mathrm{CPI}=3.74$ for the natural soil (Vertisol). The higher odd carbon number preference in the Vertisol indicates the lower stage of maturation of soil organic matter in the natural soil. The $\mathrm{CPI}_{\text {long/short }}$ homologues also confirms the predominant terrigenous source of SOM for the Vertisol and the reclaimed mine soils (RMS-G, RMS-PII). (Table 2 near here).

\section{Isoprenoids, pristane and phytane}

Pristane $\left(\mathrm{C}_{19}\right)$ and phytane $\left(\mathrm{C}_{20}\right)$ eluting just after $\mathrm{C}_{17^{-}}$and $\mathrm{C}_{18} n$-alkanes, respectively were detected in all the samples (Table 2). Pristane and phytane are normally detected in thermally mature organic matter such as petroleum and coal (Tissot \& Welte 1984). It has been considered that phytane has been preferentially synthesized in comparison to pristane as a result of phytol degradation under anaerobic sedimentary conditions. GC/MS separation allowed evaluation of $\mathrm{Pr} / \mathrm{Ph}, \mathrm{Pr} / \mathrm{nC}_{17}$ vs $\mathrm{Ph} / \mathrm{nC}_{18}$ ratios. The pristane/phytane ratios have been used as palaeoenvironmental indicators. The $\mathrm{Pr} / \mathrm{Ph}$ of $\sim 1$ or $<1$ indicate that coal has been formed under reducing environments, while higher ratios usually indicate an increased contribution from terrigenous sources (Stefanova et al. 2013). The $\mathrm{Pr} / \mathrm{Ph}$ ratios in the range of 2-3 (Table 3) are indicative of terrigeneous plant input deposited under oxic to suboxic conditions (Chaffee et al. 1986). The $\mathrm{Pr} / \mathrm{C}_{17}$ ratio was the lowest in the Vertisol (0.42) and the highest in the unreclaimed spoil (2.6), thus reflecting the higher contribution of terrestrial organic matter over the fossil one in the Vertisol and the conservation of the more degradation resistant pristane in the unreclaimed coal spoil. The higher $\mathrm{Pr} / \mathrm{C}_{17}$ ratios observed, as compared to coal (Stefanova et al. 2013) reflect the biodegradation-weathering effect exerted on coal in the spoils. In the native Vertisol, the alkane distribution $\mathrm{C}_{16}-\mathrm{C}_{33}$ was bimodal, maximizing at $\mathrm{C}_{18}$ and $\mathrm{C}_{29}$. The occurrence of pristane and phytane in the Vertisol points to contamination by a fossil fuel source and the allochthonous origin of these compounds in the SOM fraction.

URL: http://mc.manuscriptcentral.com/GAGS E-mail: galina.machulla@landw.uni-halle.de 


\section{Fatty acids}

Fatty acid distribution pattern for the reclaimed soils was unimodal ranging from $\mathrm{C}_{9}$ $\mathrm{C}_{32}$ (Figure 3), maximizing at the ubiquitous palmitic acid $\mathrm{C}_{16}$, while for the unreclaimed coal spoil the distribution is bimodal stretching from $\mathrm{C}_{5}-\mathrm{C}_{21}$ (maximizing at $\mathrm{C}_{16}$ acid) and the other encompassing longer chain members, $\mathrm{C}_{22}-\mathrm{C}_{34}$ (maximizing at $\mathrm{C}_{26}$ acid). The main sources of the long chain fatty acids are terrestrial plants (Oros et al.

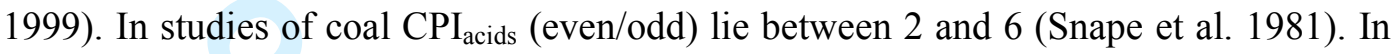
our study CPI values vary from 2.9-13 and are the lowest for the unreclaimed coal spoil and the highest for the Vertisol. For the mine soils these values are in the range 6.7-10 and reflect the increasing role of terrestrial vegetation in the formation of organic matter. The lowest CPI (2.9) for the eroded unreclaimed coal spoil reflects the higher microbial (algal) contribution to SOM and the higher maturity of SOM in the coal spoil. With respect to low molecular weight fatty acids $\leq \mathrm{C}_{20}$ intense microbial activity or algal contribution in coal is plausible (Stefanova et al. 2013). Branched fatty acids were identified in the mine soils with $i$-, ai- methyl derivatives of $\mathrm{C}_{14}, \mathrm{C}_{15}$ and $\mathrm{C}_{17}$ acids similarly to studies with low-rank coals (Del Rio et al. 1992) and are also indicators of microbial activity during sedimentation. In addition to many typical bacterial acids the spoils contained odd-numbered $\mathrm{C}_{23}$ and $\mathrm{C}_{25}$ acids, which can also originate from the inputs from higher plants (Fourcans et al. 2004) instead of being a product of anoxic phototrophic bacteria and cyanobacteria. Saturated odd-numbered fatty acids such as $\mathrm{C}_{23}, \mathrm{C}_{25}$, and $\mathrm{C}_{27}$ have been identified in the marine diatom Stauroneis amphioxys and other algal species (Rezanka \& Sigler 2009). Detection of unsaturated fatty acids, mainly palmitoleic $\left(\mathrm{C}_{16: 1}\right)$, oleic $\left(\mathrm{C}_{18: 1}\right)$ and linoleic $\left(\mathrm{C}_{18: 2}\right)$ in the natural Vertisol points to increased microbial activity in this soil. The presence of stearic acid esters in all the samples, as well as in low rank coals may be connected with chemical changes during maturation, such as hydrolysis of the esters and conversion of the acids into paraffins 


\section{Fatty alcohols}

The distributions of $n$-alkanols $\left(\mathrm{C}_{18}-\mathrm{C}_{30}\right)$ for the mine soils and $\left(\mathrm{C}_{18}-\mathrm{C}_{30}\right)$ for the native Vertisol are unimodal and showed a predominance of compounds with even carbon numbers with a maximum at $\mathrm{C}_{26}$ (Figure 4$)$. Short chain alkanols $\left(<\mathrm{C}_{22}\right)$ have been attributed to microbial sources (Robinson et al. 1984), while long chain $>\mathrm{C}_{22}$ even carbon numbered homologues are components of terrestrial higher plant leaf waxes (Rielley et al. 1991). The dominance of $\mathrm{C}_{26}$ homologue and the $\mathrm{CPI}=15.6-30.6$ suggest that these compounds originate from vascular plants including microbially synthesized compounds, as reflected by the presence of odd $\mathrm{C}$ number-homologues in the mine soils and the native soil. The very low contents of $n$-alkanols $\left(\mathrm{C}_{24}-\mathrm{C}_{28}\right)$ registered in the unreclaimed coal spoil (Figure 4) indicate that these compounds might be esterified in the macromolecular framework of coal organic matter. (Figure 2, 3, 4 near here)

\section{Resin acids}

High abundance of diterpenoid acids, i.e. abietic, dehydroabietic, pimaric and isopimaric acids were detected in the mine soils, thus confirming the conifer vegetation dominance in the formation of SOM. The presence of dehydroabietic acid and other diterpenoids, such as dehydroabietane in the unreclaimed spoil implies the conifer vegetation origin of the coal-forming mires of Pernik, as well. Abietic acid has been identified as a major compound of ancient and modern Pinaceae resins and through diagenesis leads to formation of retene via generation of intermediate compounds, e.g. dehydroabietic acid (Otto \& Wilde 2001).

\section{Sesquiterpenoids}

The following sesquiterpenoids $(<1 \%)$ were detected in the mine soils: (RMS-PI) germacrene $\mathrm{D}, \beta$-Cubebene, $\beta$-guaiene, cedrene, 4$\beta \mathrm{H}, 5 \alpha$-eremophil-1(10)-ene, 11 hydroxy, 4-isopropyl-1,6-dimethylnaphthalene (cadalene), eudesmane (UCS). Sesquiterpenoids are typical coal biomarkers originating from resinous plants and fossil 
woods (Simoneit et al. 1986) and have been also obsereved in Bulgarian Neogene coals (Stefanova et al. 2013).

\section{Diterpenoids}

High intensity saturated hydrocarbons were represented primarily by $16 \alpha(\mathrm{H})$ phyllocladane, $\mathrm{M}+{ }^{\bullet} 274$, b.p. $\mathrm{m} / \mathrm{z} 123$. Diterpenoids. i.e. 18-norabietane are typical of Gymnosperms and are common constituents of Bulgarian Neogene coals, as well (Stefanova et al. 2013). The prevalence of phyllocladane, 5-15 rel.\% in the TLE extracts of the reclaimed mine soils and the unreclaimed coal spoil provides molecular confirmation for the contribution of conifers as a source to the coal and SOM of the spoils. The aromatized tricyclic diterpenoid, viz. retene was detected in all the reclaimed and unreclaimed spoils and is a marker for wood combustion and polycyclic aromatic hydrocarbons (PAHs) source apportionment (Shen et al. $2012 \mathrm{a}, \mathrm{b}$ ). The high abundance of diterpenoids in the TLEs is an evidence for the input of higher plants sources to coal formation.

\section{Steroids}

The presence of the phytosterols, $\beta$-sitosterol and stigmasterol indicates a signal from vascular plants in the natural Vertisol and the reclaimed mine soils. The compound $5 \alpha, 17 \alpha$-pregnan-12-one can be a precursor of pregnane (De Leeuw \& Baas 1986) in kerogen, and partly a product from thermal cracking of $\mathrm{C}_{27-29}$ regular steranes $(\mathrm{Wu}$ et al. 2013). The steroid ketone viz. stigmast-4-en-3-one has been identified as a marker of fugitive dust from agricultural crop fields (Rogge et al. 2007) and is probably an intermediate in the oxidation of sterols to stanols by microbes as found in the roots of peatland plants (Huang et al. 2011). The steroid derivative ergosta-5,22-dien-3-ol, acetate, $(3 \beta, 22 \mathrm{E})$ in the reclaimed mine soils has frequently been used as a biomarker for the presence of algal matter, but has also been identified in soil humic acids esterified with carboxylic acids (Berthier et al. 2000). This marker was absent in the 
unreclaimed coal spoil, thus indicating its plant origin and the fact that soil forming processes have advanced in the mine soils. The presence of cholesterol and cholesterol derivative 4-methyl-3-[(hydroxy]cholest-5-ene $\left(\mathrm{M}+{ }^{\circ} 472\right)$ indicates a source component from fauna.

\section{Triterpenoids}

In the TLEs of the reclaimed mine soils were detected: 30-norlupan-28-oic acid; 3hydroxy-21-methoxy-20-oxo-, methyl ester and C(14a)-homo-27-norgammacer-13-en21-one, 3-methoxy, $(3 \alpha)$-, which has been identified in the neutral fraction of the benzene extractives from the bark of Pinus radiata (Weston 1973). Triterpenoids such

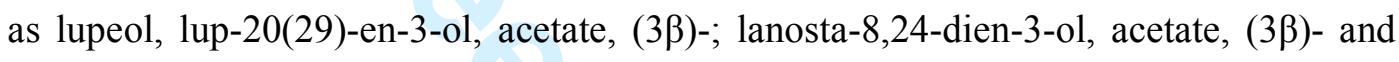
30-norlupan-28-oic acid, 3-hydroxy-21-methoxy-20-oxo-, methyl ester, (3ß)-, were also abundant in the natural Vertisol. Triterpenoids were lacking in the unreclaimed coal spoil, thus confirming their terrigenous origin from the local vegetation in the reclaimed soils and the natural soil.

\section{Contaminants}

The contaminant viz.4,4'-diacetyldiphenylmethane is a product of the photocatalytic oxidation of coal, which is selectively oxidized and partially degraded (Jianfang et al. 2007).

\section{Dicarboxylic acids}

The TLEs of the unreclaimed coal spoil contain higher abundances of $\mathrm{C}_{4}, \mathrm{C}_{6}$ dioic (adipic), and $\mathrm{C}_{9}$ (azelaic) acids. These polar compounds were suspected to stabilize hydrophobic interactions in combination with other amphiphilic and lipophilic compounds in water repellent eucalypt soils (Atanassova \& Doerr 2010). These acids were not detected at measurable abundances in the natural soil and the reclaimed soils.

\section{Soil water repellency}


The Vertisol (WDPT 1740 s) and the unreclaimed coal spoil (WDPT 8220 s) were severely and extremely water repellent (Table 1, Doerr et al. 2000), while the reclaimed mine soils were not. The severe water repellency corresponds with the higher contents of organic matter of these samples. The absolute quantification of the homologous series of alkanes, fatty acids and fatty alcohols indicates higher saturation per unit mass of substrate with long chain fatty acids $\left(>\mathrm{C}_{18}\right)$ in the unreclaimed coal spoil (UCS), in comparison with the reclaimed mine soils (RMS) and higher concentration of long chain alkanes and fatty alcohols in the Vertisol (Figures 2, 3, 4). A combination of amphiphilic compounds such as fatty acids with the hydrophobic long chain alkanes have been shown to be most effective in inducing water repellency (Mainwaring et al. 2013). Atanassova \& Doerr (2010) have found higher concentrations of long chain alkanols, alkanes and fatty acids normalised to organic carbon in water repellent sandy Australian soils with small surface area, while in the present study the same trend was observed with the Vertisol, similarly to other fine-textured soils (Doerr et al. 2006) and for the unreclaimed coal spoil (UCS) of lower bulk density, higher porosity and specific surface area (unpublished data). The higher abundance of short chain polar dicarboxylic acids in the water repellent samples can play an important role in soil water-repellency development by stabilizing the hydrophobic interactions (Atanassova \& Doerr 2010). We speculate that in the unreclaimed mine spoil water repellency is most probably caused by aliphatic or amphiphilic compounds in interstitial coal particles or forming coatings on mineral grains. In the natural Vertisol, as suggested by Doerr et al. (2000) water repellency may occur on clay aggregates of reduced surface area, thus facilitating covering by hydrophobic compounds. Conformational changes in the organic molecules may result in attachment of the polar groups of the amphiphilic and polar compounds to the mineral surfaces, exposing hydrophobic surfaces into the pore space (Atanassova $\&$ Doerr 2010). The alkaline $\mathrm{pH}$ of the reclaimed mine soils would favor deprotonation of surface sites, increase of negative surface charge and a decrease of water repellency URL: http://mc.manuscriptcentral.com/GAGS E-mail: galina.machulla@landw.uni-halle.de 
(Diehl et al. 2010). The higher concentrations of the long chain alkanes, fatty acids and alcohols are speculated to promote the high water repellency observed with the Vertisol and the unreclaimed coal spoil (UCS). The lack of water repellency in the reclaimed mine soils confirmed the positive effects of reclamation practices of originally acid coal spoils.

\section{Conclusions}

The molecular signature of the main homologous series of organic compounds and the various compounds proxies indicate both terrigenous soil borne compounds, as well as coal sources to SOM in the mine soils. Biogenic terrigenous lipids (alkanes, fatty acids and fatty alcohols) as well as coal biomarkers (abietane, phyllocladane, phytane, pristane) were most abundant in the reclaimed mine soils and the unreclaimed spoil. The presence of terrigenous steroid and triterpenoid markers in the reclaimed mine soils is an indication of the ongoing soil formation processes in these long-time reclaimed spoils-turned soils. The detection of coal biomarkers in the Vertisol showed that aerosol transfer of coal particles in the area around the mine has taken place. The higher concentrations of the long chain alkanes, fatty acids and alcohols are speculated to promote the severe and extreme water repellency observed with the Vertisol and the unreclaimed coal spoil.

On the basis of a detailed analysis of the lipid extracts of long-time reclaimed mine soils, unreclaimed coal spoil and a natural soil (Vertisol) from the area of the Pernik coal mining region, it was possible to assess sensitive molecular indicators of biogenic terrigenous and coal origin, as well as to evaluate the degree of soil recovery, and infer organic matter origin following $>20$ years of spoils reclamation.

\section{References}


Atanassova I, Doerr S. 2010. Organic compounds of different extractability in total solvent extracts from soils of contrasting water repellency. Eur J Soil Sci. 61:298313.

Atanassova I, Mills G. 2016. Biogenic and Anthropogenic Lipid Markers in Sediments from a Marsh Habitat Associated with the LCP Chemicals Superfund Site in Brunswick, Georgia, USA. Water Air Soil Poll. 227:1-13.

Barnhisel RI, Hower JM. 1997. Coal surface mine reclamation in the eastern United States: the revegetation of disturbed lands to hayland/pasture or cropland. Adv Agron. 61:233-275.

Berthier G, Dou S, Peakman T, Lichtfouse, E. 2000. Identification of bound alcohols in soil humic acids by gas chromatography-mass spectrometry. Eur J Mass Spectrom. $6,439-441$.

Bryselbout C, Henner P, Lichtfouse E. 1998. Fossil fuel biomarkers in plant waxes as pollution parameters. Sci Total Environ. 222:201-204.

Chaffee AL, Perry GJ, Johns RB. 1981. Carboxylic acids and coal structure. In: Gorbaty ML \& Quchi K, editors. Coal Structure. Washington: American Chemical Society; p. $113-131$.

Chaudhuri S, McDonald LM, Skousen J \& Pena-Yewtukhiw EM. 2015. Soil organic carbon molecular properties: effects of time since reclamation in a minesoil chronosequence. Land Degrad Dev. 26:237-48.

Claassens S, Van Rensburg PJ \& Van Rensburg L. 2006. Soil microbial community structure of coal mine discard under rehabilitation. Water Air Soil Poll. 174:355366.

de Leeuw JW \& Bass M. 1986. Early diagenesis of steroids. In: Johns RB, editor. Biological Markers in the Sedimentary Record. Amsterdam: Elsevier; p. 102-127. 
Diehl D, Bayer JV, Woche SK, Bryant R, Doerr SH, Schaumann GE. 2010. Reaction of soil water repellency to artificially induced changes in soil $\mathrm{pH}$. Geoderma. 158:375384.

Doerr SH, Shakesby RA, Dekker LW, Ritsema CJ. 2006. Occurrence, prediction and hydrological effects of water repellency amongst major soil and land-use types in a humid temperate climate. Eur J Soil Sci. 57:741-754.

Doerr SH, Dekker LW, Ritsema CJ, Shakesby RA, Bryant R. 2002. Water repellency of soils: the influence of ambient relative humidity. Soil Sci Soc Am J. 66:401-405.

Doerr SH, Shakesby RA, Walsh RPD. 2000. Soil water repellency: its causes, characteristics and hydro-geomorphological significance. Earth-Sci Rev. 51:33-65.

Fourcans A, De Oteyza TG, Wieland A, Sole A, Diestra E, Van Bleijswijk J. et al. 2004. Characterization of functional bacterial groups in a hypersaline microbial mat community (Salins-de-Giraud, Camargue, France). FEMS Microbiol Ecol. 51:5570.

Ganev, S, Arsova A. 1980. Methods of determining the strongly acidic and the slightly acidic cation exchange in soil. Soil Sci Agrochem. 15: 19-33. (In Bulgarian).

Gerke HH, Hangen E, Schaaf W, Hüttl RF. 2001. Spatial variability of potential water repellency in a lignitic mine soil afforested with Pinus nigra. Geoderma. 102:255274.

Gushevilov J, Paskaleva K. 1977. Composition of clay minerals in marlstone piles of Pernik coal basin and their importance for agricultural reclamation. Soil Sci Agrochem. 6:14-22. (In Bulgarian)

Haigh MJ, Gentcheva-Kostadinova S. 2002. Ecological erosion control on coal-spoil banks: an evaluation. Ecol Eng. 18:371-377.

Haigh M, Gentcheva-Kostadinova S. 2007. Geomorphological Impact of Erosion Control Measures on a Steep Coal-Spoil Embankment, Pernik, Bulgaria. Geogr Fis Dinam Quatern. 30:179-183.

URL: http://mc.manuscriptcentral.com/GAGS E-mail: galina.machulla@landw.uni-halle.de 
Hristov B, Shishkov T, Katchova V, Atanassova E, Atanassova I. 2015. Basic Chemical and physico-chemical characteristics of soils and substrates in the region of Pernik coal mine basin. In: Soils and Agrotechnology in a Changing World. Digital Book of Proceedings; 2015 May 11-15; Sofia (Bulgaria): ISSAPP "Nikola Pushkarov"

Huang X, Wang C, Zhang J, Wiesenberg GL, Zhang Z, Xie S. 2011. Comparison of free lipid compositions between roots and leaves of plants in the Dajiuhu Peatland, central China. Geochem J. 45:365-373.

ISO 11508:1998. Soil quality-Determination of particle density. Available from http://www.iso.org/iso/catalogue_detail.htm?csnumber=19459. Accessed 29 May 2016.

IUSS Working Group WRB. 2015. World Reference Base for Soil Resources 2014, update 2015. International soil classification system for naming soils and creating legends for soil maps. World Soil Resources Reports No. 106. FAO, Rome.

Jianfang J, Qiyu W, Yingyu W, Weicheng T, Bo X. 2007. GC/MS Analysis of Coal Tar Composition Produced from Coal Pyrolysis. Bull Chem Soc Ethiopia. 21:229240.

Kononova MM, 1966. Soil Organic Matter: its nature, its role in soil formation and in soil fertility. $2^{\text {nd }}$ ed. Oxford: Pergamon Press.

Krümmelbein J, Bens O, Raab T, Anne Naeth M. 2012. A history of lignite coal mining and reclamation practices in Lusatia, eastern Germany. Can J Soil Sci. 92:53-66.

Lichtfouse E, Bardoux G, Mariotti A, Balesdent J, Ballentine DC, Macko SA. 1997. Molecular, ${ }^{13} \mathrm{C}$, and ${ }^{14} \mathrm{C}$ evidence for the allochthonous and ancient origin of $\mathrm{C}_{16^{-}}$ $\mathrm{C}_{18} n$-alkanes in modern soils. Geochim Cosmochim Ac. 61:1891-1898.

Macdonald SE, Landhäusser SM, Skousen J, Franklin J, et al. 2015. Forest restoration following surface mining disturbance: challenges and solutions. New Forest. 46: 703-732. 
Mainwaring K, Morley CP, Doerr SH, Douglas P, et al. 2004. Role of heavy polar organic compounds for water repellency of sandy soils. Environ Chem Lett. 2:3539.

Mainwaring K, Hallin IL, Douglas P, Doerr SH, Morley CP. 2013. The role of naturally occurring organic compounds in causing soil water repellency. Eur J Soil Sci. 64: $667-680$.

Matsumoto K, Kawamura K, Uchida M, Shibata Y. 2007. Radiocarbon content and stable carbon isotopic ratios of individual fatty acids in subsurface soil: Implication for selective microbial degradation and modification of soil organic matter. Geochem J. 41:483-492.

Niwa Y, Yumura M, Ishikawa K, Kuriki Y, Kawamura M. 1988. Structural identifications of straight-chain fatty acids and esters in coal extracts by linked scanning mass spectrometry. Fuel. 67:98-103.

Oros DR, Standley LJ, Chen X, Simoneit BR. 1999. Epicuticular wax compositions of predominant conifers of western North America. Z Naturforsch C. 54:17-24.

Otto A, Wilde V. 2001. Sesqui-, di- and triterpenoids as chemosystematic markers in extant conifers-A review. Bot Rev. 67:141-238.

Park JH, Li X, Edraki M, Baumgartl T, Kirsch B. 2013. Geochemical assessments and classification of coal mine spoils for better understanding of potential salinity issues at closure. Environ Sci Proc Imp. 15:1235-1244.

Řezanka T, Sigler K. 2009. Odd-numbered very-long-chain fatty acids from the microbial, animal and plant kingdoms. Prog Lipid Res. 48:206-238.

Rieley G, Collier RJ, Jones DM, Eglinton G. 1991. Biogeochemistry of Ellesmere Lake, U.K. I. Source correlation of leaf wax inputs to the sedimentary lipid record. Org Geochem. 17:901-912.

Robinson N, Cranwell PA, Finlay BJ, Eglinton G. 1984. Lipids of aquatic organisms as potential contributors to lacustrine sediments. Org Geochem. 6:143-152.

URL: http://mc.manuscriptcentral.com/GAGS E-mail: galina.machulla@landw.uni-halle.de 
Rogge WF, Medeiros PM, Simoneit BRT. 2007. Organic marker compounds in surface soils of crop fields from the San Joaquin Valley fugitive dust characterization study. Atmos Environ. 4:8183-8204.

Shen G, Tao S, Wei S, Zhang Y, et al. 2012a. Retene emission from residential solid fuels in China and evaluation of retene as a unique marker for soft wood combustion. Environ Sci Technol. 46:4666-4672.

Shen G, Tao S, Wei S, Zhang Y, et al. 2012b. Emissions of parent, nitro, and oxygenated polycyclic aromatic hydrocarbons from residential wood combustion in rural China. Environ Sci Technol. 46:8123-8130.

Quénéa K, Largeau C, Derenne S, Spaccini R, et al. 2006. Molecular and isotopic study of lipids in particle size fractions of a sandy cultivated soil (Cestas cultivation sequence, southwest France): Sources, degradation, and comparison with Cestas forest soil. Org Geochem. 37:20-44.

Simoneit BR, Grimalt JO, Wang TG, Cox RE, et al. 1986. Cyclic terpenoids of contemporary resinous plant detritus and of fossil woods, ambers and coals. Org Geochem. 10:877-889.

Snape CE, Stokes BJ, Bartle KD. 1981. Identification of straight-chain fatty acids in coal extracts and their geochemical relation with straight-chain alkanes. Fuel. 60:903-908.

Stefanova M, Kortenski J, Zdravkov A, Marinov S. 2013. Paleoenvironmental settings of the Sofia lignite basin: Insights from coal petrography and molecular indicators. Int J Coal Geol. 107:45-61.

Stefanova M, Gonsalvesh L, Marinov S, et al. 2016. Reductive pyrolysis of Mioceneaged lignite humic acids, Bulgaria. Fuel. 165:324-330.

Tissot BP, Welte DH. 1984. Petroleum Formation and Occurrence. Berlin: SpringerVerlag. 
Ussiri DA, Lal R. 2005. Carbon sequestration in reclaimed minesoils. Crit Rev Plant Sci. 24:151-165.

Van Bergen PF, Bull ID, Poulton PR, Evershed RP. 1997. Organic geochemical studies of soils from the Rothamsted Classical Experiments-I. Total lipid extracts, solvent insoluble residues and humic acids from Broadbalk Wilderness. Org Geochem. 26: $117-135$.

Vlad PF, Russo AG, Koltsa MN, Paukov VN. 1971. Dehydroabietane from the oleoresin of Pinus pallasiana. Chemistry of Natural Compounds, 7, 16-18. Weston, R. 1973. Neutral extractives from Pinus radiata bark. Aust J Chem. 26: 2729-2734.

Wang J, Yang R, Bai Z. 2015. Spatial variability and sampling optimization of soil organic carbon and total nitrogen for Minesoils of the Loess Plateau using geostatistics. Ecol Eng. 82: 159-64.

Wu L, Liao Y, Fang Y, Geng A. 2013. The comparison of biomarkers released by hydropyrolysis and Soxhlet extraction from source rocks of different maturities. Chinese Sci Bull. 58: 373-383.

Zhao Z, Shahrour I, Bai Z, et al. 2013. Soils development in opencast coal mine spoils reclaimed for 1-13 years in the West-Northern Loess Plateau of China. Eur J Soil Biol. 55: 40-46. 
Figure 1. Total ion current chromatogramme of the reclaimed mine soil (a) under pine vegetation (RMS-PI), (b) under grass vegetation (RMS-G), (c) of the natural soil (Vertisol), (d) of the unreclaimed coal spoil (UCS). Compounds in order of elution:

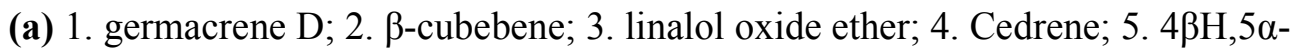
Eremophil-1(10)-ene, 11-(hydroxy); 6. benzaldehyde, 3-methoxy-4-(hydroxyl)-; 7. cyclopentene, 1,2-dimethyl-4-methylene-3-phenyl-; cadalene; 8. 2-Pentadecanone, 6,10,14-trimethyl- ; 9. 17,7 4b,8-dimethyl-2-isopropylphenanthrene, 4b,5,6,7,8,8a,9,10-

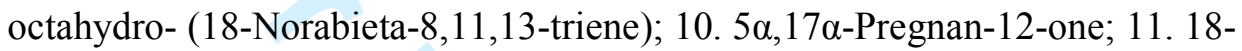
Norabietane (262MW); 11a. 20,65. 4-isopropyl-7,11-dimethyl-3,7,11cyclotetradecatrienone; 11b. cyclohexene, 4-pentyl-1-(4-propylcyclohexyl)- (2,3\%); 12. phyllocladane; 13. 2-nonadecanone IS; 14. 4,4'-diacetyldiphenylmethane (234); phenanthrene, 1-methyl-7-(1-methylethyl)-(retene); 15. pimaric acid; isopimaric acid ; methyl dehydroabietate; 10,13-octadecadiynoic acid, methyl ester; 16. dehydroabietic acid; 17. abietic acid (1,3\%); eicosanoic acid; alkane; ph; alkanol; alkane; docosanoic acid; alkane; alkanol; bismonostearin; 18. tetradecane, 1,1'-thiobis-; alkane; alkanol; ergosta-5,22-dien-3-ol, acetate, (3 $\beta, 22 \mathrm{E})$-; alkane; alkanol; alkanol; $\beta$-Sitosterol; 19. stigmast-4-en-3-one; 20. 30-norlupan-28-oic acid, 3-hydroxy-21-methoxy-20-oxo-,

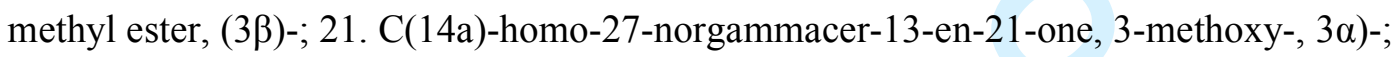
(b) 2-pentadecanone, 6,10,14-trimethyl-; $\mathrm{C}_{14}$ acid; 1. 18-Norabietane; 4-isopropyl-7,11dimethyl-3,7,11-cyclotetradecatrienone ; cyclohexene, 4-pentyl-1-(4-propylcyclohexyl)2. phyllocladane; 7-isopropyl-1,1,4a-trimethyl-1,2,3,4,4a,9,10,10a-octahydrophenanthrene (dehydroabietane); 3. 4,4'-diacetyldiphenylmethane; 4. pimaric acid; 2hydroxy-3-allyl-5-t-butylbiphenyl; isopimaric acid; 5. methyl dehydroabietate; 6. dehydroabietic acid; 7. abietic acid; 8. eicosanoic acid; 9. $\mathrm{C}_{22}$ alkanol; 2-monostearin; 10. 2,3-bis[(hydroxy]propyl stearate; 11. 4-methyl-3-[hydroxy]cholest-5-ene; 12.

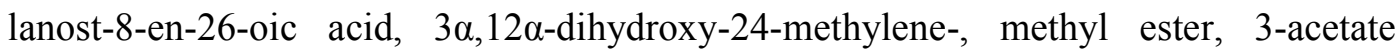
(suspected); stigmast-4-en-3-one; 13. 30-norlupan-28-oic acid, 3-hydroxy-21-methoxyURL: http://mc.manuscriptcentral.com/GAGS E-mail: galina.machulla@landw.uni-halle.de 
20-oxo-, methyl ester, (3ß)- ; 14. C(14a)-homo-27-norgammacer-13-en-21-one, 3methoxy-, $(3 \alpha)$-;

(c) 3-methyl-1-hydroxybut-2-ene, 1. hydrocinnamic acid; 2. benzaldehyde, 3-methoxy4-hydroxy-; 3. 18-norabietane; phyllocladane; 7-isopropyl-1,1,4a-trimethyl1,2,3,4,4a,9,10,10a-octahydrophenanthrene (dehydroabietane); 9,12-octadecadienoic acid (Z,Z)-; 2-monostearin; bismonosterain; alkane; alkanol; cholesterol; 4-methyl-3[(hydroxy]cholest-5-ene (M+. 472); stigmasterol; alkanol; 4. $\beta$-sitosterol; lupeol (triterpenoid); 3-O-Acetyl-6-methoxy-cycloartenol (suspected) 5. 4,4-dimethyl-3hydroxy]cholesta-8,24-diene; 6. lup-20(29)-en-3-ol, acetate, (3ß)-; 7. lanosta-8,24-dien3-ol, acetate, (3ß)-; 8. 30-norlupan-28-oic acid, 3-hydroxy-21-methoxy-20-oxo-, methyl ester, (3ß)-; 9. triterpenoid: $\mathrm{m} / \mathrm{z} 55,73,95,131,147,189,301,393,453,468,\left(\mathrm{M}+{ }^{*}\right.$ $604 ?)$

(d) butanedioic acid; benzaldehyde, 4-hydroxy-; $\mathrm{C}_{10}$ acid; cedrane; $\mathrm{C}_{6}$ dioic acid; naphthalene, decahydro-1,4a-dimethyl-7-(1-methylethyl)-,[1S-(1 $\alpha, 4 \mathrm{a} \alpha \alpha, 7 \alpha, 8 \mathrm{a} \beta)]-(4 \alpha \mathrm{H}-$ eudesmane); hexanedioic acid, (adipic acid); benzaldehyde, 3-methoxy-4-[(hydroxy]-; 1. benzoic acid, 4-hydroxy-; $\mathrm{C}_{12}$ acid; 2. naphthalene, 1,6-dimethyl-4-(1-methylethyl)(cadalene); alkanes; 3. azelaic acid; pentadecanone; $\mathrm{C}_{14}$ acid; alkane; 4 . tetracyclo[10.3.3.0.0(14,17)]octadecan-14-ol; 19,4 n-C15 acid; kaur-15-ene, $(5 \alpha, 9 \alpha, 10 \beta)$-; 5. dibutyphthalate; 6. 18-norabietane; 4-isopropyl-7,11-dimethyl-3,7,11 cyclotetradecatrienone; 7. cyclohexene, 4-pentyl-1-(4-propylcyclohexyl)-; 8 . phyllocladane; 9. 7-isopropyl-1,1,4a-trimethyl-1,2,3,4,4a,9,10,10a-octahydrophenanthrene (dehydroabietane)(270); 10. 4,4'-diacetyldiphenylmethane; $\mathrm{C}_{18: 1}$ acid; phenanthrene, 1-methyl-7-(1-methylethyl)-; $\mathrm{C}_{18}$ acid; 5,7,9(11)-androstatriene, 3hydroxy-17-oxo-; 11. methyl pimaran-18-oate ; 12. dehydroabietic acid; $\mathrm{C}_{20}$ acid; alkane; $\mathrm{C}_{21}$ acid; contaminant; alkane; 7-oxodehydroabietic acid; $\mathrm{C}_{22}$ acid; alkane; $\mathrm{C}_{23}$ 
acid; alkane; $\mathrm{C}_{24}$ acid; alkane; $\mathrm{C}_{25}$ acid; $\mathrm{C}_{26}$ acid; alkane; $\mathrm{C}_{27}$ acid; $\mathrm{C}_{28}$ acid; $\mathrm{C}_{29}$ acid; $\mathrm{C}_{30}$ acid.

Figure 2. Akane distribution in (a) Vertisol; (b) reclaimed mine soil under grass (RMSG); (c) reclaimed mine soil under pine (RMS-PI); (d) reclaimed mine soil under pine (RMS-PII); (e) unreclaimed coal spoil (UCS); (f) reclaimed mine soil under pine (RMSPI) as per unit mass of soil; (g) Vertisol, as per unit mass of soil. Numbers on the abscissa correspond to carbons in the alkane chain.

Figure 3. Fatty acids distribution in (a) Vertisol; (b) reclaimed mine soil under grass (RMS-G); (c) reclaimed mine soil under pine (RMS-PI); (d) reclaimed mine soil under pine (RMS-PII); (e) unreclaimed coal spoil (UCS); (f) reclaimed mine soil under pine (RMS-PI) as per unit mass of soil; (g) unreclaimed coal spoil (UCS) as per unit mass of substrate. Numbers on the abscissa correspond to carbons in the fatty acid chain.

Figure 4. Fatty alcohols distribution in (a) Vertisol; (b) reclaimed coal spoil under grass (RMS-G); (c) reclaimed mine soil under pine (RMS-PI); (d) reclaimed mine soil under pine (RMS-PII); (e) unreclaimed coal spoil (UCS); (f) reclaimed mine soil under pine (RMS-PI) as per unit mass of soil; (g) Vertisol as per unit mass of soil. Numbers on the abscissa correspond to carbons in the fatty alcohol chain. 